\title{
A Theoretical Study of the Draft Reading Device
}

\author{
Kouhei HIRONO*, Wataru SERA*, Masaki FUCHI* and Kinzo INOUE*
}

\begin{abstract}
SHIN NIHON KENTEI KYOKAI (New Japan Surveyors \& Sworn Measurers Association that is abbreviated as "SK") has developed the device to support to read draft that is named "KENDRAFT" and operated it in the fields. To read draft is very important for the mercantile marine trading. However, it has not been improved to advance an accuracy, and still involved risky work.

This paper describes the result of experiments to clarify the principal and performance of the KENDRAFT. And its purpose is to contribute toward increasing fairness and safety at draft reading.

Keywords : draft survey, experiment in the basin, multiple linear regression analysis
\end{abstract}

\section{Introduction}

SHIN NIHON KENTEI KYOKAI (New Japan Surveyors \& Sworn Measurers Association that is abbreviated as "SK") provides some survey and measuring services on neutral stand in mercantile marine trading. There is a draft survey in one of its activities. The present measuring method is watching by naked eyes. When sea surface is moving by wave or swell, an imaginary average surface level is set near by a draft mark for each the ship's mate, the shipper's agent, and the surveyor. There can be differences among these persons. Differences of reading become a cause of troubles and delay of ship's departure. On the other hand, draft reading is risky work because it is needed to climb down and up a ladder to approach the draft mark. It has been requested that a draft reading is done accurately and promptly.

The SK developed a device to support draft reading with indication of stable sea surface level in waves or swells. It was named "KENDRAFT" and applied for patent (P2003-137178A: Japan Patent Office). It has been operated in many fields and obtained its reliability.

This paper describes the result of experiments to clarify a principal and performance of the KENDRAFT. The purpose of this paper is to increase accuracy and safety of draft reading with certified index by a device like KENDRAFT.

\section{Outline of the device}

\subsection{Structure}

Figure 1 shows a sketch of construction of KENDRAFT. The main structure is the pipe made of acrylic fiber of transparency, length $50 \mathrm{~cm}$. Its inner diameter is $16 \mathrm{~mm}$ and there is one buoy ball (painted on clear red) that is called "marker" in this paper. The hose made of the vinyl chloride is connected on lower end of the main structure. The hose has $5 \mathrm{~m}$ length in default. And the pipe made of stainless steel is connected on the end of the hose. The stainless pipe is weight to pull the hose in a perpendicular below and it has the filter that prevents garbage from going into the hose.

The main structure is installed on the chassis that has strong magnet wheels. The chassis has the trestle to support the mirror or the video camera.

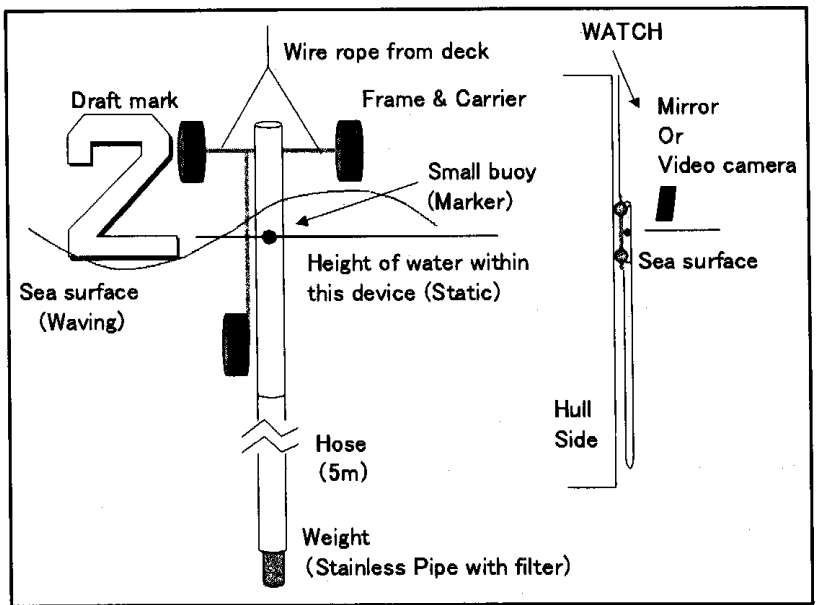

Fig.1 Structure of the KENDRAFT

* Regular member, Faculty of Maritime Sciences Kobe University, 5-1-1 Fukae-minamimachi, Higashinada-ku, Kobe, Japan, Zip Code 658-0022 hirono@maritime.kobe-u.ac.jp 


\subsection{Operation}

That chassis is hung from the deck over the handrail. It is lowered along with draft marks. And it is fixed at the height that the approximate average of sea surface level within the length of the main structure.

The marker (the buoy ball in the main structure) points the level of the draft mark. It is shown by the mirror, or through the video monitor. The ship's mate, the shipper's agent, and the surveyor confirm the draft with this common index (See Figure 2).
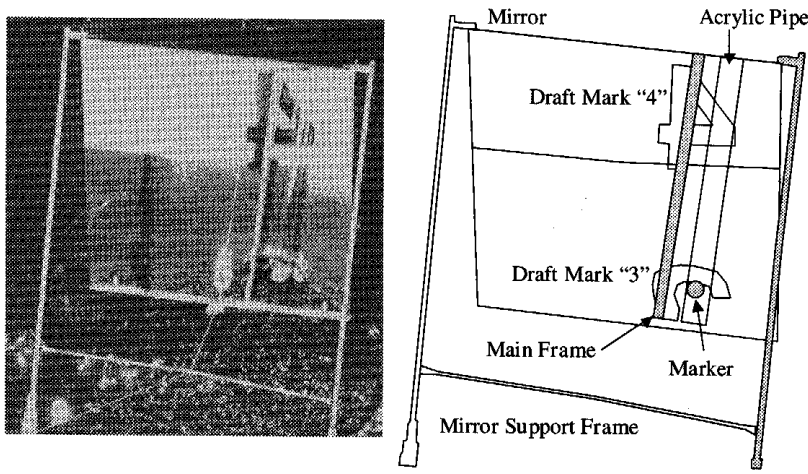

Fig.2 Marker and draft marks in the mirror attached to KENDRAFT

\section{Present ground and the purpose of experiments}

The KENDRAFT makes a pillar of water in its structure when it is in operation. The perpendicular movement of this water pillar is caused by the gyration of water particle at the depth corresponds to length of the hose.

As well known, the deeper depth becomes, the more the radius of the gyration of the water particle becomes small. Therefore, it appears that there only have to be the hose of enough length. At present, the hose length is $5 \mathrm{~m}$. And actually, it is said that the marker is stable even in any waves or swells encountered in Japanese ports.

The purpose is to clarify the relationship between the perpendicular movement of the water pillar that is expressed by the marker's amplitude and the wave (height, length) and the hose (length), first. The second is to confirm that the length of hose, i.e., the depth is the only reason to reduction the marker's amplitude.

According to these purposes, four experiments were planned. The first one was a main experiment to execute cases parametrically with the shallow-water basin in the
Faculty of Maritime Sciences Kobe University (KUMS). The second one was a supplemental experiment to confirm the result of the first with the deep-water basin in the Graduate School of Engineering Osaka University. The third one was a supplemental experiment, too. It was done at the actual shipboard for a final confirmation of the result obtained in these two laboratories. And forth one was aimed to approach to the principal of this device done at the shallow-water basin in KUMS.

\section{Main experiment}

\subsection{Settings, measurement, and analysis}

\subsubsection{Settings and measurement at the shallow-water basin}

This basin has $60 \mathrm{~m}$ length, $6 \mathrm{~m}$ width, and $1.4 \mathrm{~m}$ depth. There is a window at about middle position of longitudinal side. The water inside can be seen through that window.

The KENDRAFT was set up on the frame composed by angle brackets. This frame was set up on inner side of the window, and the video camera was set up on outside. On the other hand, the water level sensor was set up near that frame (See Figure 3).

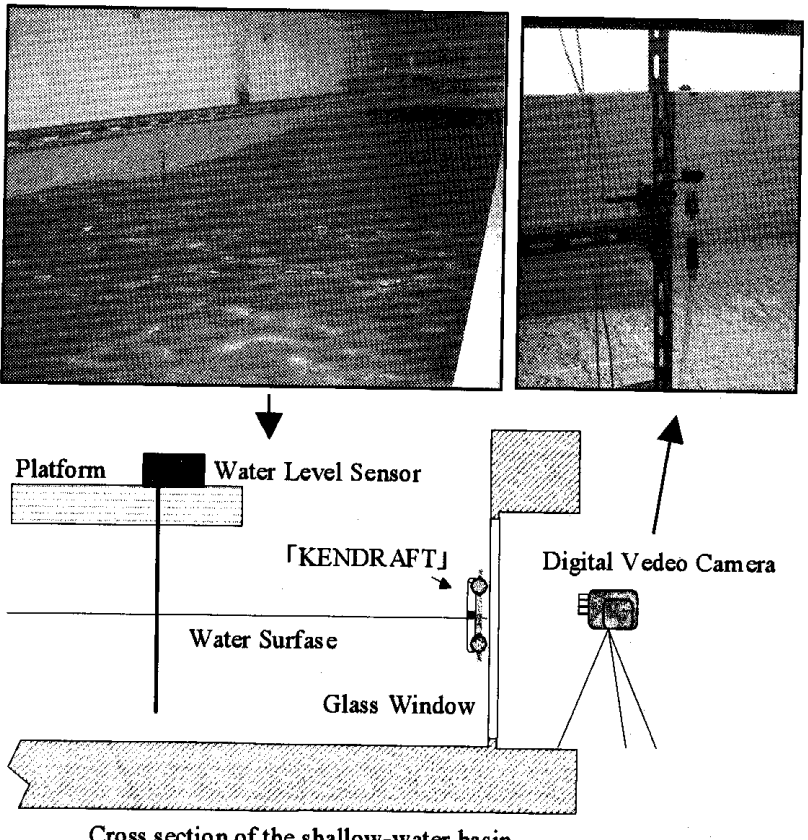

Fig.3 Settings of measurement for marker, and water level

\subsubsection{Analysis Method}

The digital image data recorded by the video camera was transferred to snapshots for each frame. In this case, the video camera recorded 29.97 images per second 
according to the National Television System Committee standard. Therefore, the interval of two consecutive images is $1 / 29.97$ seconds.

A color character of the marker was identified through sampling. A color character means a combination of magnitude of "Red", "Green", and "Blue". After several pixels within the marker's shape were gathered, a relationship between "Red" and "Green", and a relationship between "Red" and "Blue" were specified. In the same way, the water level's color character was identified.

The program that developed originally, detected the marker position and water level by their color characters in the image, i.e., pixel coordinates. And this program transferred the position to the actual scale in centimeter, and appended it to the file with time stamp derived from the image interval and counts. The time sequential data of water level recorded by the sensor were merged this file. As the image processing did not cover the whole height of wave, wave levels detected from images were used only for deciding the sensor data's start line to be referred.

Figure 4 shows a sample of result of analysis. The horizontal axis means time in seconds. The vertical axis means the height of wave and the marker's amplitude in centimeters.

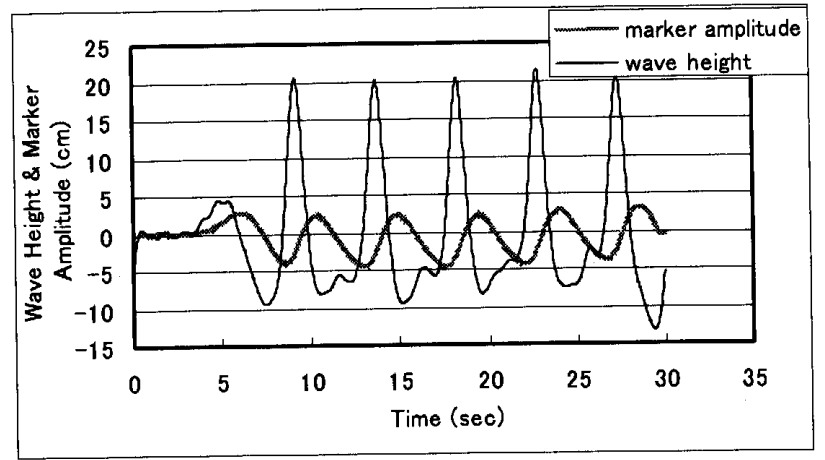

Fig.4 Sample of time sequence, wave height and marker's amplitude

\subsection{Cases of the main experiment}

Table 1 shows cases of the main experiment. There were 29 cases in all. Those number in each sub tables means case name for convenience sake.

And symbols assignment as blow:

$\mathrm{d}$ : Length of hose $(\mathrm{cm})$

$\mathrm{H}$ : Height of wave (cm)

$\lambda$ : Length of wave (m)

W.P.: Period of wave (sec)
Xmean: Mean of marker's deviation from level " 0 " (cm)

Xamp: Mean of marker's amplitude (cm)

Table 1 Cases in the main experiment Hose Length $(d)=120 \mathrm{~cm}$

\begin{tabular}{|c|c|c|c|c|c|}
\hline \multicolumn{6}{|c|}{ Hose Length (d) $=120 \mathrm{~cm}$} \\
\hline $\begin{array}{c}\text { Wave } \\
\text { Length } \\
(\lambda)\end{array}$ & $\begin{array}{c}\text { Wave } \\
\text { Period } \\
\text { (W.P.) }\end{array}$ & $30 \mathrm{~cm}$ & $22.5 \mathrm{~cm}$ & $15 \mathrm{~cm}$ & $7.5 \mathrm{~cm}$ \\
\hline $15 \mathrm{~m}$ & $4.6 \mathrm{sec}$ & 1 & 2 & 3 & 4 \\
\hline $11.25 \mathrm{~m}$ & $3.5 \mathrm{sec}$ & 5 & & 8 & \\
\hline $7.5 \mathrm{~m}$ & $2.5 \mathrm{sec}$ & 6 & & 9 & \\
\hline $3.75 \mathrm{~m}$ & $1.6 \mathrm{sec}$ & 7 & & 10 & \\
\hline
\end{tabular}

\begin{tabular}{|c|c|c|c|c|c|}
\hline \multicolumn{7}{|c|}{ Hose Length $(\mathrm{d})=90 \mathrm{~cm}$} \\
\hline $\begin{array}{c}\text { Wave } \\
\text { Length } \\
(\lambda)\end{array}$ & $\begin{array}{c}\text { Wave } \\
\text { Period } \\
\text { (W.P.) }\end{array}$ & \multicolumn{5}{|c|}{ Wave Height $(H)$} \\
\hline $15 \mathrm{~m}$ & $4.6 \mathrm{sec}$ & 11 & $22.5 \mathrm{~cm}$ & $15 \mathrm{~cm}$ & $7.5 \mathrm{~cm}$ \\
\hline $11.25 \mathrm{~m}$ & $3.5 \mathrm{sec}$ & 15 & & 13 & 14 \\
\hline $7.5 \mathrm{~m}$ & $2.5 \mathrm{sec}$ & 16 & & & \\
\hline $3.75 \mathrm{~m}$ & $1.6 \mathrm{sec}$ & 17 & & 18 & 19 \\
\hline
\end{tabular}

\begin{tabular}{|c|c|c|c|c|c|}
\hline \multicolumn{6}{|c|}{ Hose Length $(d)=60 \mathrm{~cm}$} \\
\hline \multirow{2}{*}{$\begin{array}{l}\text { Wave } \\
\text { Length } \\
(\lambda)\end{array}$} & \multirow{2}{*}{$\begin{array}{l}\text { Wave } \\
\text { Period } \\
\text { (W.P.) }\end{array}$} & \multicolumn{4}{|c|}{ Wave Height $(\mathrm{H})$} \\
\hline & & $30 \mathrm{~cm}$ & $22.5 \mathrm{~cm}$ & $15 \mathrm{~cm}$ & $7.5 \mathrm{~cm}$ \\
\hline $15 \mathrm{~m}$ & $4.6 \mathrm{sec}$ & 20 & 21 & 22 & 23 \\
\hline $11.25 \mathrm{~m}$ & $3.5 \mathrm{sec}$ & 24 & & & \\
\hline $7.5 \mathrm{~m}$ & $2.5 \mathrm{sec}$ & 25 & & & \\
\hline $3.75 \mathrm{~m}$ & $1.6 \mathrm{sec}$ & 26 & & 27 & 28 \\
\hline $1.885 \mathrm{~m}$ & $1.1 \mathrm{sec}$ & & & 29 & \\
\hline
\end{tabular}

Number in the tables means case name

\subsection{Result of analysis}

\subsubsection{Marker's amplitude caused by wave height, wave period, and hose length}

Figure 5 shows the relationship between the wave height and the marker's amplitude. Sub figure (1) shows the relationship in the case that the wave length $(\lambda)$ is $15 \mathrm{~m}$, and (2) is in the case that the $\lambda$ is $3.75 \mathrm{~m}$.

Figure 6 shows the relationship between the wave period and the marker's amplitude. And Figure 7 shows the relationship between the hose length and marker's amplitude. For each sub figures (1) show the relationship in the case that the wave height $(\mathrm{H})$ is $30 \mathrm{~cm}$, and (2) are in the case that the $\mathrm{H}$ is $15 \mathrm{~cm}$.

According to these figures, the larger wave height becomes, the longer wave period becomes, and shorter hose length becomes, the more the marker's amplitude becomes large. In figure 5 , there is a significant difference of the marker's amplitude between sub figure (1): $\lambda=15$ $\mathrm{m}$ and sub figure (2): $\lambda=3.75 \mathrm{~m}$. The significant difference in figure 5 is not seen in figure 6 , i.e., comparison of wave height. Therefore, it seems that the wave length more influences marker's amplitude than the wave height. 


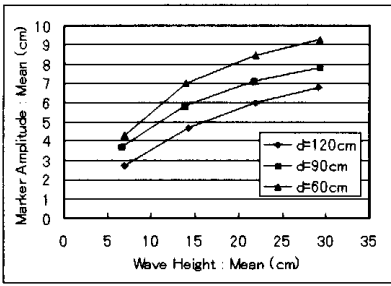

(1) Wave length is $15 \mathrm{~m}$

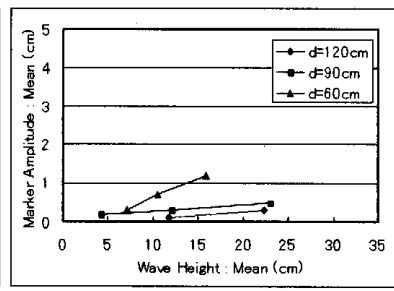

(2) Wave length is $3.75 \mathrm{~m}$
Fig. 5 Wave height to marker's amplitude

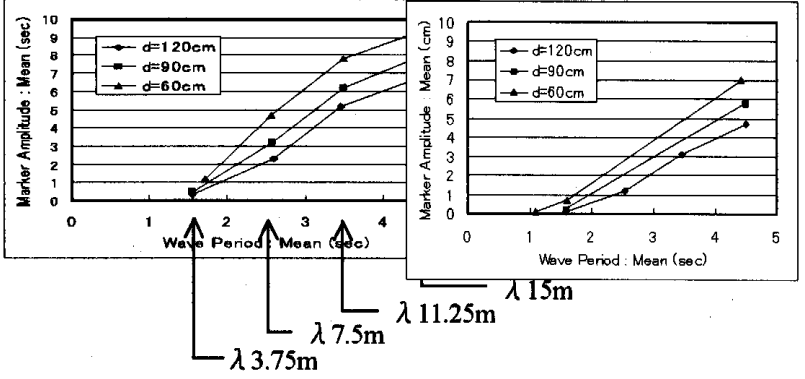

(1) Wave height is $30 \mathrm{~cm}$

(2) Wave height is $15 \mathrm{~cm}$

Fig. 6 Wave period to marker's amplitude

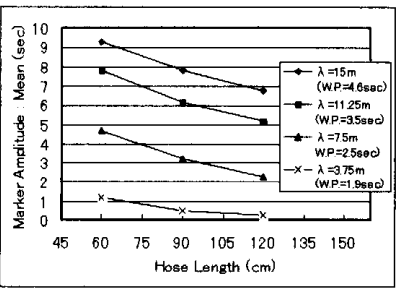

(1) Wave height is $30 \mathrm{~cm}$

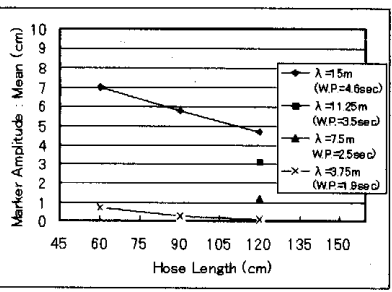

(2) Wave height is $15 \mathrm{~cm}$
Fig. 7 Hose length to marker's amplitude

\subsubsection{Marker' $s$ deviation from level " 0 "}

Figure 8 shows the relationship between the wave height and the marker's vertical movement (deviation from level " 0 " that means the water level as the condition is clam). Figure 9 shows the relationship between the wave period and the marker's deviation.

According to these figures, the longer wave period becomes, and the larger wave height becomes, the more the mean of deviation becomes low.

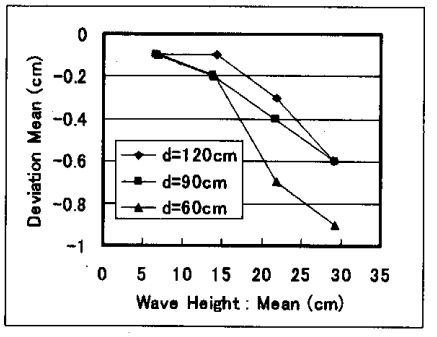

Fig. 8 Wave height to marker's deviation

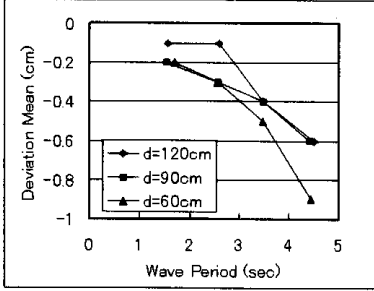

(1) Wave height is $30 \mathrm{~cm}$

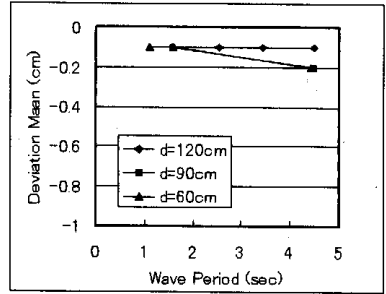

(2) Wave height is $15 \mathrm{~cm}$
Fig. 9 Wave period to marker's deviation

\subsubsection{Wave period and the marker's period}

Figure 10 shows the relationship between the wave period and the marker's period in vertical movement (deviation). There are liner lines $(y=x)$ in each sub figures for convenience sake. According to these figure, the marker's movement synchronizes with the wave period.

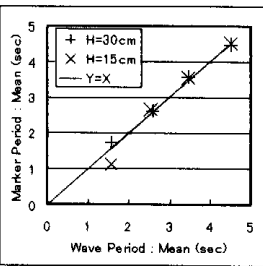

(1) $\mathrm{d}=120 \mathrm{~cm}$

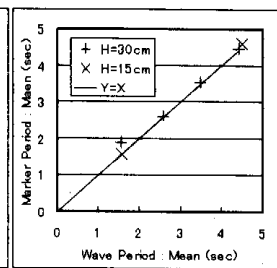

(2) $d=90 \mathrm{~cm}$

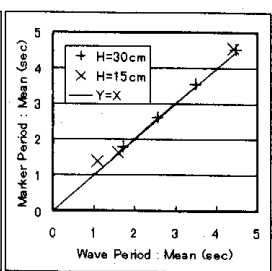

(3) $\mathrm{d}=60 \mathrm{~cm}$
Fig.10 Wave period to marker's period

\subsubsection{Phase difference between the wave and the marker}

Figure 11 shows the relationship between the wave height and the phase difference. Figure 12 shows the relationship between the wave period and the phase difference. The phase difference was defined by the time (in second) form coming of the peak of the wave to coming of the peak of the marker's deviation.

According to these figures, the longer hose length becomes, the more the phase difference becomes large. And according to figure 12 , it seemed that the wave period influences the phase difference.

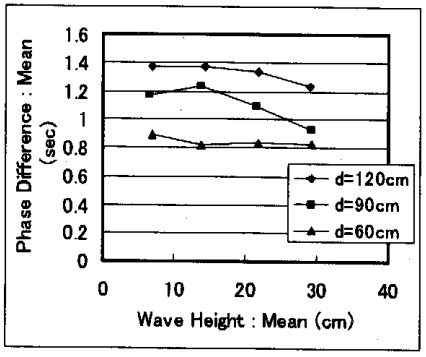

Fig.11 Wave height to phase difference 

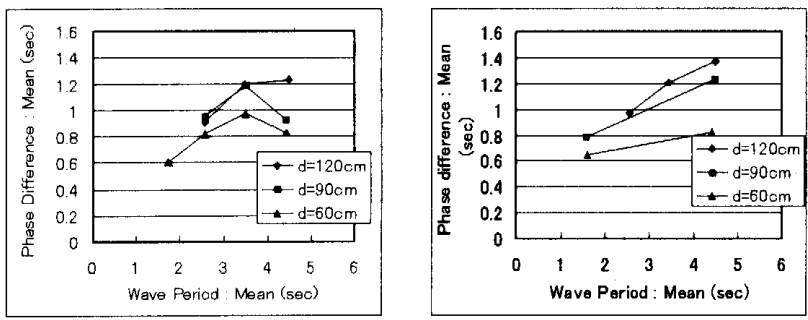

Fig.12 Wave period to phase difference

\subsubsection{Regression analysis}

The interested point in operation is that the KENDRAFT indicates the average sea surface without moving. Therefore, we tried to predict the marker's amplitude and deviation with these three parameters using the multiple linear regression analysis. Formula 1 provides the relationship between the dependent variable (the marker's amplitude) and explanatory variables (wave height, wave period, and hose length). And formula 2 provides the relation about the marker's deviation. Each formula also has extremely high value of multiple correlation coefficients. Therefore, these formulas can be used for estimation of marker's amplitude and deviation.

$\mathrm{X}_{\mathrm{amp}}=0.14633 \times \mathrm{H}+1.67147 \times$ W.P. $-0.04344 \times \mathrm{d} \cdots(1)$

Number of samples is 29 , multiple correlation coefficient is 0.96816

$\mathrm{X}_{\text {mean }}=-0.02029 \times \mathrm{H}-0.05742 \times$ W.P. $+0.00308 \times \mathrm{d}$

Number of samples is 29 , multiple correlation coefficient is 0.90188

Figure 13 shows a map for guideline. The horizontal axis means the wave height $(\mathrm{cm})$, and vertical axis means the wave period $(\mathrm{sec})$. These are three lines in the graph that track points of combinations give the amplitude " 0 " for each hose length. If it is plotted below area, it means that the marker's amplitude is negligible.

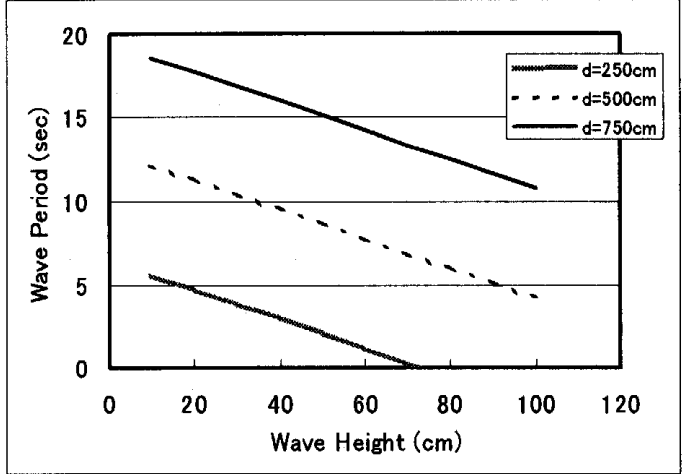

Fig.13 Map for operational guideline

\section{Sub experiments}

\subsection{Outlines of sub experiments}

There were two experiments for supplement. One was done at the deep-water basin in Osaka Univ. The basin has $100 \mathrm{~m}$ length, $5 \mathrm{~m}$ width, and $4.3 \mathrm{~m}$ depth. It does not have the window for observation; therefore, movement of the marker was watched by its video camera.

Another one was done at actual ship whose length of all is $230 \mathrm{~m}$ and mold depth is $19 \mathrm{~m}$, during unloading bulk cargo. It was fine and sea smooth. Therefore, we made the chartered small boat $(\mathrm{Loa}=12 \mathrm{~m}$, Hose power $=70 \mathrm{ps}$ ) run by the draft mark and appear waves compulsory.

\subsection{Verification of prediction formula}

Figure 14 shows the result of experiment at the deep-water basin and actual shipboard. The eclipse means that the marker moved at these conditions when the hose length was set value the arrow points.

In any case, the marker moved on the condition of is located above the line of the criteria. It is compatible between the result of the supplementary experiments and the prediction formula.

The prediction formula was able to be verified partially.

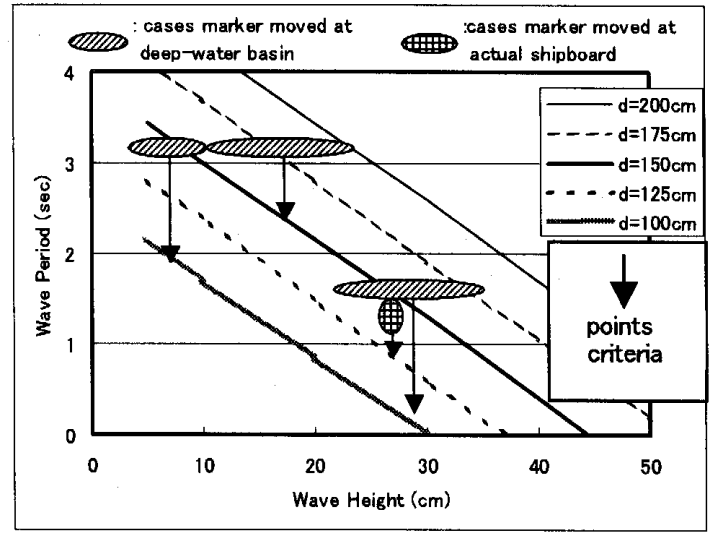

Fig.14 Zone where marker moved

\section{For the theoretical study}

\subsection{Supplemental case on the shallow-water basin}

There was a doubt whether the hose length was only reason to reduce the marker's amplitude. If it were so, the same length solid pipe would get similar effect. A supplemental case was done to confirm this hypothesis. Figure 15 shows the result of this case. In this case (the 
pipe length is $120 \mathrm{~cm}$, the wave height is $30 \mathrm{~cm}$, and the wave length is $15 \mathrm{~m}$ ), there was no delay, that is, the phase difference was " 0 ", and marker's whole amplitude could not measure because it was too large. For the comparison, figure 4 is shown again as figure 16 . It seemed that the resistance in the hose (pipe) caused the difference of marker's movement. The hypothesis was denied.

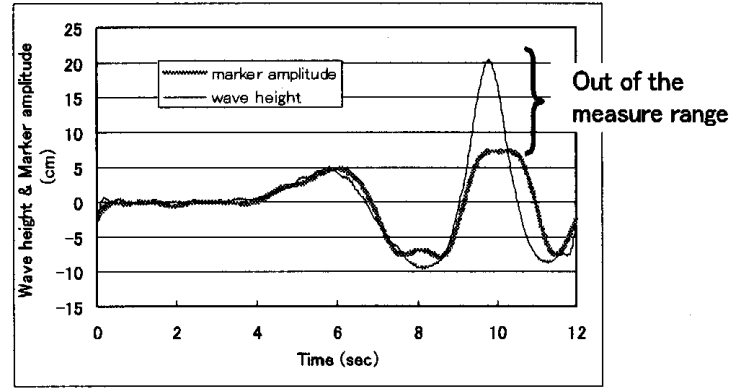

Fig. 15 Marker movement, hose is a solid pipe

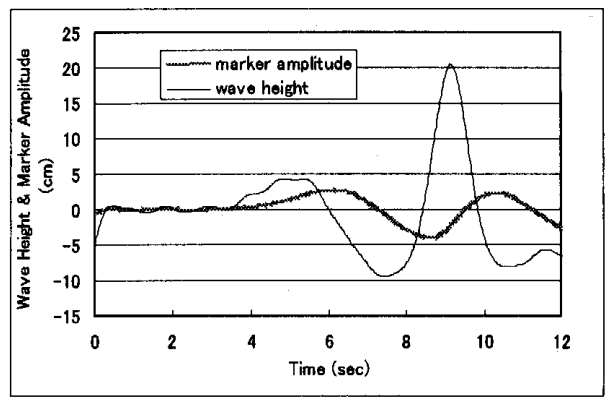

Fig. 16 (Fig. 4) Marker movement, KENDRAFT

\subsection{Resistance in the hose}

Additional cases were done to compare resistor's effect. Figure 17 shows results of these cases. In that figure, "Pipe with Resistor" means a solid pipe that was stuffed with the net of nylon, and "Pipe without Resistor" means solid pipe with no stuff. According to this figure, it seemed that the KENDRAFT has a large resistance, and not only the hose length but also resistance in hose reduces the marker's amplitude.

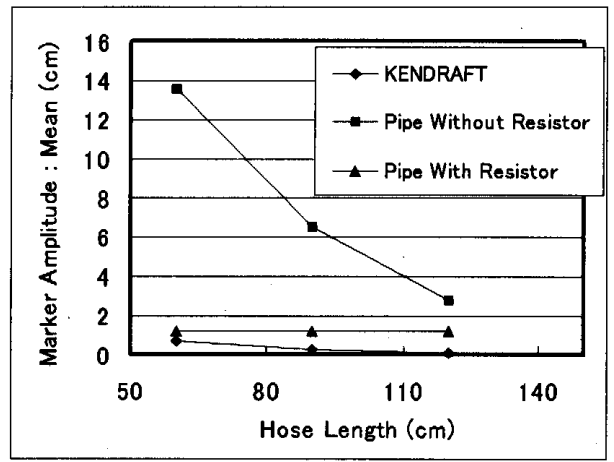

Fig. 17 Resistance in the hose to marker's amplitude

\section{Conclusions}

(1) On the KENDRAFT, prediction formula was obtained and it was verified by the experiment with deep-water basin and actual shipboard, partially. To advance the verification, it will be needed that the shore based measurement with large and long waves.

(2) Not only the hose length but also the resistance in the hose reduces the marker's amplitude. However, a model of dynamics has not been clarified, yet. It will reinforce prediction formula and may be lead something to substitute for the hose.

\section{質疑応答}

津金正典 (東海大学):

以前、南米、豪州のうねりの影響を受ける鉱石船バ 一スで、船体中央付近の喫水を測定するために、透 明ホースを下げて行った経験があります。本装置の ように遠隔で契水が正確に得られることはメリット があります。水位の移動平均等の統計処理を加えら れたらと思います。

また、本装置の内径は精度に影響するのでしょうか。 広野康平:

実務経験に基づいたメリットのご指摘に感謝します。 計測や統計処理の工夫については、今後とも継続し ていく予定です。また、精度、つまり、マーカの上 下動に関する理論的考察もあわせて進めていく予定 です。

装置内径の影響については今回の実験では明らかに なっておりません。理論的考察の中で配慮されるも のと考えています。 